\title{
Remote Sensing of Spatial and Temporal Vegetation Patterns in Two Grazing Systems
}

\author{
Lisandro J. Blanco, ${ }^{1}$ Carlos A. Ferrando, ${ }^{2}$ and Fernando N. Biurrun ${ }^{3}$ \\ Authors are ${ }^{1}$ Natural Resource Scientist and ${ }^{2}$ Range Scientist, Estación Experimental Agropecuaria La Rioja, \\ Instituto Nacional de Tecnología Agropecuaria (INTA), CC 26, 5380 Chamical, La Rioja, Argentina; and ${ }^{3}$ Biologist, Estación Experimental Agropecuaria \\ La Rioja, Instituto Nacional de Tecnología Agropecuaria (INTA), CC 26, 5380 Chamical, La Rioja, Argentina, and Universidad Nacional de La Rioja \\ (UNLAR), Castro Barros 557, 5380 Chamical, La Rioja, Argentina.
}

\begin{abstract}
One constraint that range scientists must face in grazing studies is the lack of accurate and repeatable techniques for discriminating grazing effects from both temporal variability and spatial heterogeneity of vegetation. Both forms of variability contribute to inconsistent grazing system effects on vegetation response and forage production in semiarid ecosystems. Remote sensing may be an efficient tool for detecting differences in spatial and temporal patterns of grazing impact on vegetation. The purpose of this study was to evaluate the spectral data derived from satellite images as a tool for comparing grazing system impacts on spatial and temporal vegetation patterns. We evaluated the effect of two grazing systems, "Continuous" (C) and “Two-Paddocks Rest-Rotation" (TPRR), on vegetation cover from 1996 to 2006 in a semiarid ecosystem of Argentina. We compared grazing effects on vegetation cover using two indices derived from the Normalized Difference of Vegetation Index (NDVI) data from Landsat Thematic Mapper images. We observed a slight advantage in NDVI improvement for the TPRR over the C. Even though, in both grazing systems, an upward vegetation trend occurred only in areas located far from the watering points, TPRR showed higher relative vegetation cover near the watering point than C. We consider this methodology an important step for monitoring vegetation changes and making management decisions in livestock systems of semiarid regions because grazing system impacts may be compared for both spatial and temporal vegetation patterns. However, we think that the key next step is to develop procedures that discriminate between forage and nonforage components.
\end{abstract}

\section{Resumen}

Un problema que los científicos de pastizales tienen que enfrentar en estudios de pastoreo es la falta de técnicas exactas y repetibles para separar los efectos del pastoreo debido a la variación temporal o a la heterogeneidad espacial de la vegetación. Ambas formas de variación contribuyen a la inconsistencia en los efectos de los sistemas de pastoreo sobre la respuesta de la vegetación y producción de forraje en ecosistemas semiáridos. El uso de sensores remotos puede ser una herramienta eficiente para la detección de diferencias en los patrones espaciales y temporales por el impacto del pastoreo en la vegetación. El propósito de este estudio fue el de evaluar el uso de datos espectrales derivados de imágenes de satélite como una herramienta para la comparación del impacto de los sistemas de pastoreo en los patrones temporales y espaciales de la vegetación. Evaluamos el efecto de dos sistemas de pastoreo, Contínuo (C) y Descanso rotacional de dos potreros (TPRR) sobre la cobertura vegetal de 1996 a 2006 en un ecosistema semiárido de Argentina. Comparamos los efectos del pastoreo sobre la cobertura vegetal utilizando dos índices derivados del Índice de Diferencia Normalizada de la vegetación (NDVI) a partir de datos de imágenes de Landsat Thematic Mapper. Observamos una ligera ventaja en el mejoramiento del NDVI para el TPRR sobre el C. Aunque en ambos sistemas de pastoreo la tendencia ascendente de la vegetación solo ocurrió en áreas localizadas lejos de los aguadas, TPRR mostró una mayor cobertura vegetal relativa cerca de los aguadas que el C. Consideramos esta metodología como un importante paso para el monitoreo de cambios en la vegetación así como para la toma de decisiones en el manejo del ganado en regiones semiáridas debido a que el impacto de los sistemas de pastoreo puede compararse en ambos patrones de la vegetación, temporal y espacial. Sin embargo, pensamos que el próximo paso clave es el desarrollo de procedimientos que discriminen entre los componentes forrajeros y no forrajeros.

Key Words: grazing systems, Landsat Thematic Mapper, Normalized Difference of Vegetation Index (NDVI), semiarid ecosystem, spatial heterogeneity, vegetation dynamics

\section{INTRODUCTION}

Detecting grazing effects on plant communities is difficult because of temporal and spatial variability in vegetation structure and function. In arid and semiarid ecosystems the

Research was funded in part by Instituto Nacional de Tecnología Agropecuaria (INTA), the Asociación Cooperadora INTA EEA La Rioja and the Secretaría de Ciencia y Técnica de la Nación (PID 135/2000).

Correspondence: Lisandro Javier Blanco, Natural Resource Area, Estación Experimental Agropecuaria La Rioja, Instituto Nacional de Tecnología Agropecuaria (INTA), Chamical (La Rioja), 5380, Argentina. Email: Iblanco@correo.inta.gov.ar

Manuscript received 14 October 2008; manuscript accepted 14 June 2009. variability in plant cover and production is mainly associated with water availability, principally precipitation amount and distribution (Noy Meir 1973). Vegetation spatial patterns vary in scale from a few millimeters to many kilometers and are the result of different ecological processes (Crawley 1996). These ecological processes can be categorized as disturbances (grazing, fires, and floods), biotic processes (inseeding, individual replacement, secondary succession), and environmental constraints (microclimate, topography, soil patterns, precipitation; Levin 1978; Urban et al. 1987).

One constraint that range scientists face in grazing studies is the availability of accurate and repeatable techniques able to separate grazing effects from both temporal variability and 


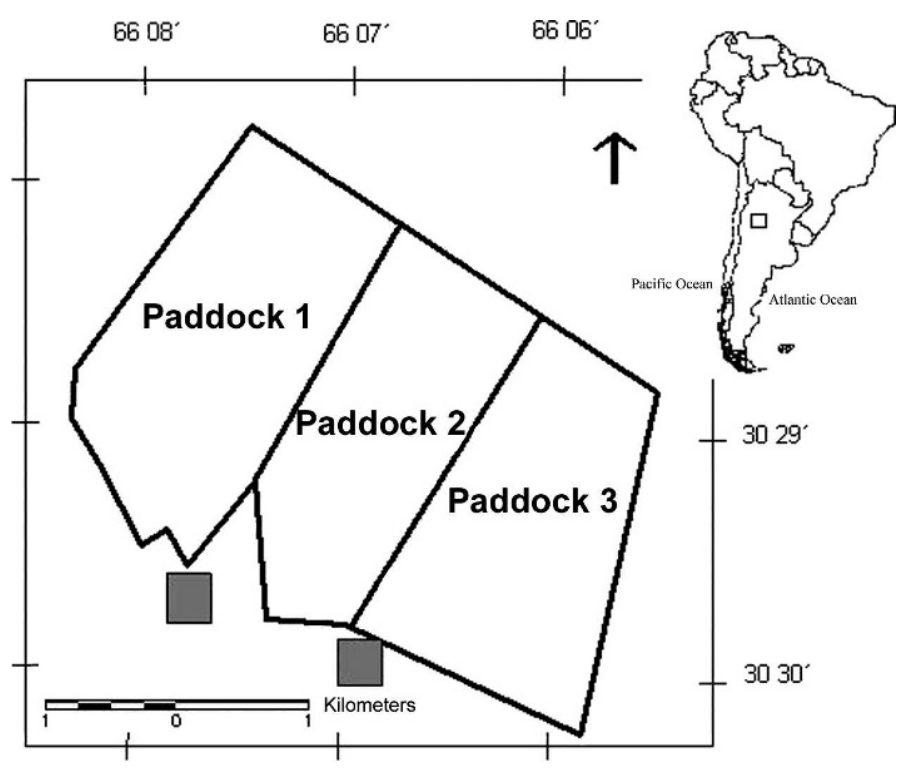

Figure 1. Location of the Las Vizcacheras Experimental Ranch in northern Argentina (lat $30^{\circ} 29^{\prime} \mathrm{S}$, Iong $66^{\circ} 07^{\prime} \mathrm{W}$ ). Black lines indicate fences of a continuous grazing system (Paddock 2) and two paddocks of a rest rotation grazing system (paddock 1 and paddock 3 ); gray squares indicate locations of the watering points.

spatial heterogeneity of vegetation (Bastin et al. 1993). The results of grazing system effects on vegetation dynamic and forage production in semiarid ecosystems are inconsistent. Holecheck et al. (2002) suggested that rotation grazing systems had generally been more beneficial to vegetation dynamics than continuous grazing systems in the humid rangelands, but no clear differences were detected in semiarid and arid areas. In a recent review, Briske et al. (2008) demonstrates that continued advocacy for rotational grazing is based on perception and anecdotal interpretation, rather than on the preponderant experimental evidence. We think that traditional field-based monitoring may not be appropriate to detect differences in grazing system effects on arid and semiarid vegetation, because the high temporal variability and spatial heterogeneity of this type of vegetation would mask the true impacts of grazing systems.

Remote sensing-based techniques are powerful tools in solving such difficulties because they offer significant advantages related to their high temporal frequency and complete spatial coverage (Pickup et al. 1994). Vegetation indexes (i.e., Normalized Difference of Vegetation Index [NDVI]) derived from multispectral satellite images play a significant role for vegetation cover qualitative and quantitative evaluation by contrasting intense chlorophyll pigment absorption in the red against the high reflectivity of plant materials in the nearinfrared (Tucker 1979). NDVI is a good estimator of synthetic parameters of vegetation structure and function, such as leaf area index and absorbed photosynthetically active radiation (Baret and Guyot 1991; Sellers et al. 1992; Gower et al. 1999; Paruelo et al. 2004) and vegetation cover (Paruelo and Golluscio 1994).

Two of the main remote sensing-based strategies that have been extensively used for grazing impact on vegetation research are the grazing gradient technique (Lange 1969; Pickup and

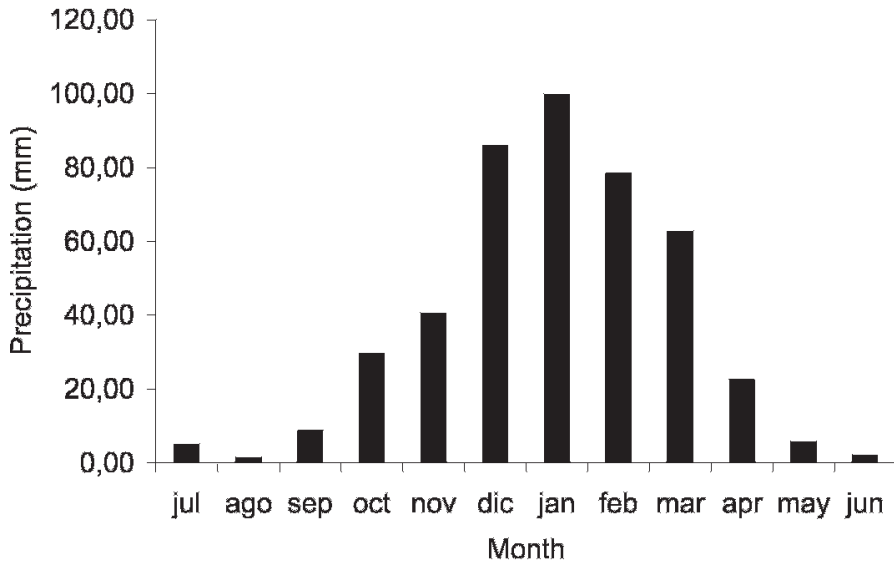

Figure 2. Mean monthly precipitation for $1980-2006$ for the "Las Vizcacheras" Experimental Ranch.

Chewings 1994; Lind et al. 2003) and matched-pair-site technique (Bryant et al. 1990; Aguilera et al. 1998). The use of paired sites is useful for the following: 1) differences in soil type, vegetation species composition, topography, and geology are minimized and 2) the proximity of both sites minimizes meteorological differences attributable to time lags in air mass movement (Bryant et al. 1990).

Even though remote sensing techniques have been used for detecting grazing impacts on vegetation (Washington-Allen et al. 2006), these techniques have not been used in comparative studies between grazing systems. The purpose of this study was to evaluate the spectral data derived from satellite images as a tool for comparing grazing system impacts on spatial and temporal vegetation patterns.

\section{MATERIALS AND METHODS}

\section{Study Site}

This study was conducted at "Las Vizcacheras" Experimental Ranch (lat $30^{\circ} 27^{\prime} \mathrm{S}$, long $66^{\circ} 11^{\prime} \mathrm{W}$ ), located in La Rioja Province, Argentina (Fig. 1). The climate of the region is semiarid, characterized by hot summers and mild winters. January has the highest average temperature $\left(26^{\circ} \mathrm{C}\right)$, whereas July is the coldest month $\left(11^{\circ} \mathrm{C}\right.$; Morello et al. 1985). The frostfree period is 289 d from August to June (Bazán 1993). Longterm average annual precipitation is $469 \pm 121 \mathrm{~mm}$, with $80 \%$ falling between November and March (Fig. 2). According to Romero et al. (1995), soils in the site are Aridisols and Entisols. Current vegetation is characterized by a continuous shrubland with isolated trees and patches of grass. Dominant woody plant genera include Larrea, Aspidosperma, Prosopis, and Mimozyganthus. Dominant grass genera are Pappophorum, Trichloris, Setaria, Aristida, and Neobouteloua. The growing season generally extends from November to March, matching the seasonal precipitation distribution (Anderson et al. 1977).

We evaluated the effect of two grazing systems, "Continuous" (C) and "Two-Paddocks Rest-Rotation" (TPRR) on vegetation cover from 1996 to 2006 when C and TPRR were applied in three contiguous paddocks (Fig. 1). TPRR was applied to paddocks no. 1 and 3 (441 ha and 384 ha, respectively), and C was applied to paddock no. 2 (347 ha). 
Table 1. Landsat Thematic Mapper scenes list that includes acquisition date and minimum digital number for the red and near-infrared wavelengths of band widths $(0.63-0.69 \mu \mathrm{m}$ and $0.76-0.90 \mu \mathrm{m}$, respectively) used for Normalized Difference of Vegetation Index estimations.

\begin{tabular}{llrc}
\hline & & \multicolumn{2}{c}{ Minimum digital number } \\
\cline { 3 - 4 } Growth period & Acquisition date & Red & Infrared \\
\hline $1987-1988$ & 17 March 1988 & 10 & 7 \\
$1988-1989$ & 20 March 1989 & 11 & 26 \\
$1989-1990$ & 23 March 1990 & 10 & 13 \\
$1990-1991$ & 27 April 1991 & 9 & 8 \\
$1991-1992$ & 13 April 1992 & 10 & 8 \\
$1992-1993$ & 11 February 1993 & 18 & 35 \\
$1993-1994$ & 21 February 1994 & 13 & 8 \\
$1994-1995$ & 22 April 1995 & 9 & 23 \\
$1995-1996$ & 7 March 1996 & 12 & 31 \\
$1996-1997$ & 27 April 1997 & 10 & 18 \\
$1997-1998$ & 4 March 1998 & 13 & 14 \\
$1998-1999$ & 17 April 1999 & 9 & 7 \\
$1999-2000$ & 18 March 2000 & 13 & 8 \\
$2000-2001^{1}$ & 9 February 2001 & 19 & 22 \\
$2001-2002^{1}$ & 17 April 2002 & 13 & 26 \\
$2002-2003^{1}$ & 20 April 2003 & 13 & 17 \\
$2003-2004$ & 26 February 2004 & 17 & 34 \\
$2004-2005$ & 23 March 2005 & 8 & 9 \\
$2005-2006$ & 22 February 2006 & 17 & 22 \\
\hline
\end{tabular}

${ }^{1}$ Scenes Landsat ETM+, where digital number was corrected following radiometric crosscalibration proposed by Teillet et al. (2001).

Stocking rate in each of the grazing systems was 0.104 animal units $(\mathrm{AU}) \cdot \mathrm{ha}^{-1}$. Paddocks under TPRR alternatively received 1 -yr graze and 1-yr rest, so that each paddock of the TPRR grazing system received a $0.208-\mathrm{AU} \cdot \mathrm{ha}^{-1}$ stocking rate during the period when each paddock was grazed. July was the paddock rotation month. Vegetation and grazing history were similar among paddocks before grazing system application (continuous grazing and stocking rate). However, the stocking rate was not always the same for the three paddocks in some years.

\section{Image Processing}

We compared grazing effects on vegetation cover using the NDVI data from Landsat Thematic Mapper (TM) images, because the Landsat program provides long-term spectral data of high spatial resolution (Washington-Allen et al. 2006). NDVI is a good estimator of the amount of photosynthetically active radiation intercepted by the green canopy (Baret and Guyot 1991; Sellers et al. 1992; Gower et al. 1999; Paruelo et al. 2004) and hence of vegetation cover (Paruelo and Golluscio 1994). We used one scene per year (Table 1). March and April scenes were selected because these months ensured that ephemeral species were avoided, and perennial species had completed their seasonal growth but had not begun to senesce. According to Blanco et al. (2008), spatial and temporal patterns of grazing effect on vegetation can be detected during those months using NDVI data.

Image rectification and registration were performed using ERDAS Imagine software. A network of ground control points was selected throughout each scene.
We used the nearest neighbor resampling approach, which preserves recorded radiances, because it is important to compare original values in change detection studies (Jensen 1996). Registration error (mean value of all scenes) was 1.30 pixels (39 m).

We estimated the NDVI of each scene considering the atmospheric effects (Song et al. 2001) as

$$
\begin{aligned}
\mathrm{NDVI}= & {[(\mathrm{TM} 4-\mathrm{TM} 3)-(\mathrm{A} 4-\mathrm{A} 3)] } \\
& \div[(\mathrm{TM} 4+\mathrm{TM} 3)-(\mathrm{A} 4+\mathrm{A} 3)],
\end{aligned}
$$

where TM4 and TM3 are digital numbers for near-infrared and red reflectance, and A4 and A3 are the additive atmospheric effects for TM4 and TM3, respectively (Table 1). Atmospheric effects were estimated by simple dark object subtraction (Chavez 1989) as minimum digital number. Thus, A3 and A4 were selected as minimum digital number with at least 1000 pixels in the histogram for the entire scene (Teillet and Fedosejevs 1995). The surface of Olta Lake, a deep clean water reservoir, was used as the dark object.

We observed a close relationship between NDVI (March) and precipitation (November to March) values $(P<0.01$ and $r^{2}=0.70$; see Fig. 3). Considering that a high proportion of NDVI interannual variability is explained by the precipitation interannual variability, we need to reduce the effect of precipitation on NDVI values for detecting grazing effects. Therefore, we annually estimated two indexes. The first index, relative difference index (RDI), was calculated as

$$
\mathrm{RDI}=\left[\left(\mathrm{NDVI}_{\mathrm{TPRR}}-\mathrm{NDVI}_{\mathrm{C}}\right) / \mathrm{NDVI}_{\mathrm{C}}\right] \times 100
$$

RDI was estimated from 1988 to 1994 (before grazing systems started) and from 1996 to 2006 (after grazing systems started). The relationship between grazing system NDVI differences and $\mathrm{NDVI}_{\mathrm{C}}$ allows us to reduce precipitation effects on NDVI absolute value. The second index used was NDVI/Pr, where Pr is growing season precipitation from 1 November to the date of Landsat TM scene acquisition (Prince et al. 1998; Holm et al. 2003). NDVI/Pr was estimated from 1996 to 2006 for both grazing systems. Similar to RDI, NDVI/Pr calculation allows us to reduce precipitation effects on NDVI absolute value. Moreover, NDVI/Pr can be estimated for each pixel, which allows us a detailed analysis of NDVI trend spatial patterns.

\section{Statistical Analysis}

Linear regression analysis, considering RDI data as the dependent variable and time ( $\mathrm{yr}$ ) as the independent variable, was used to detect temporal tendencies in RDI data during the grazing systems application period (1996-2006). We performed RDI regression analysis for the whole paddock and for three zones located at different distances from the watering point: "near zone" (0 to $1000 \mathrm{~m})$, “intermediate zone" (1 000$2000 \mathrm{~m}$ ), and "far zone" (more than $2000 \mathrm{~m}$ ).

Linear regression analysis between NDVI/Pr (dependent variable) and year (independent variable) was performed for each pixel in both grazing systems. We considered the straightline slope value for each pixel as annual NDVI/Pr change rate. 

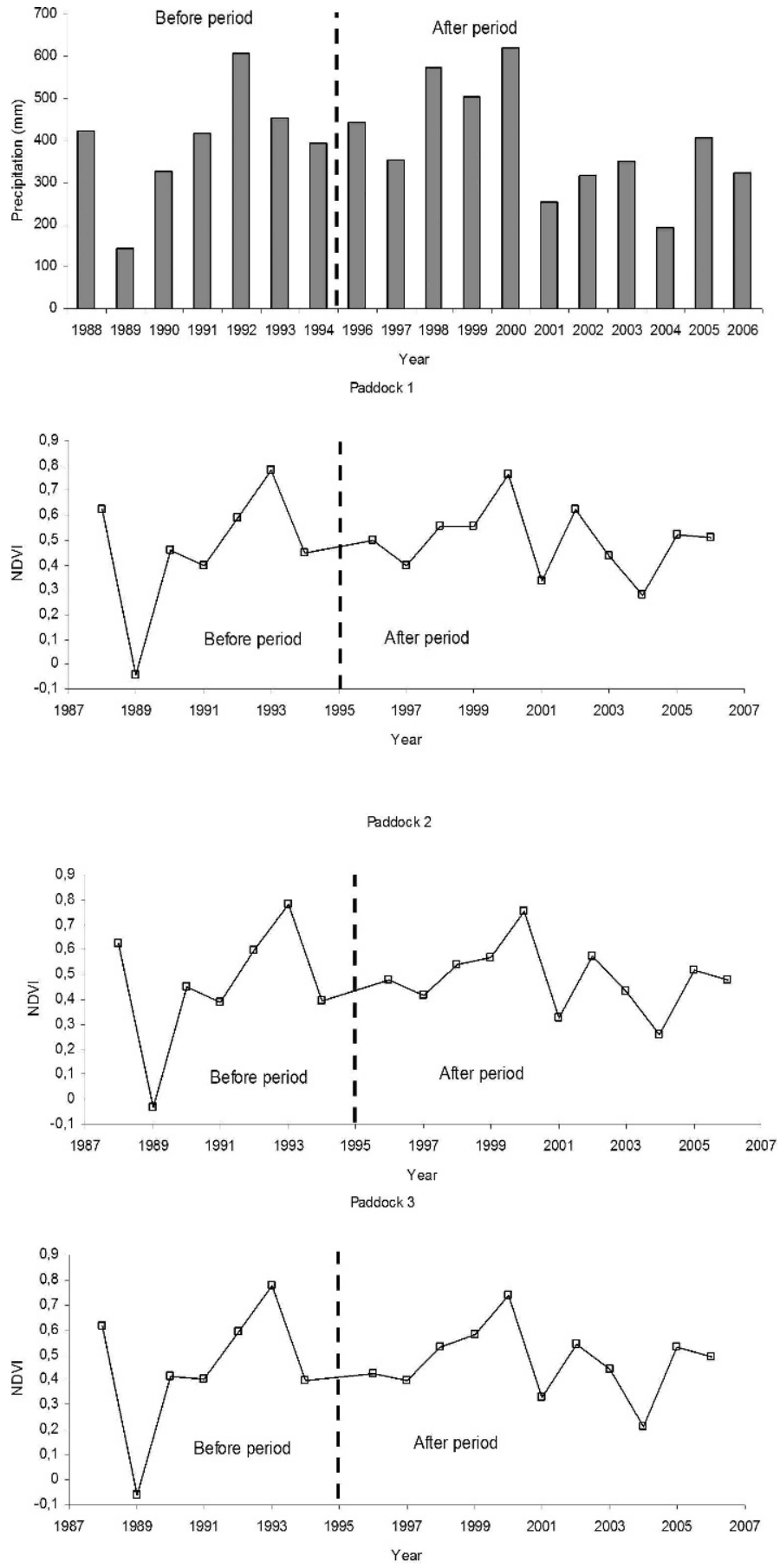

Figure 3. Total precipitation received per growth period, since start of growth period (1 November) to acquisition date (top panel), and longterm Normalized Difference of Vegetation Index data series (1988-2006) for Paddock 1 (second panel), Paddock 2 (third panel), and Paddock 3 (bottom panel). Vertical dashed line indicates the intervals before (19881994) and after (1996-2006) grazing system application.

Then we estimated the relative frequency distribution of annual NDVI/Pr change rate for each of the grazing systems. Finally, the difference in frequency distribution of annual NDVI/Pr change rate between grazing systems was tested with the Kolgomorov-Smirnov $z$ procedure.

We categorized the annual NDVI/Pr change rate for each pixel as positive or negative $(P<0.10)$, and even $(P>0.10)$ to visualize spatial patterns of vegetation dynamics. In addition, we used linear regression to analyze the relationship between annual NDVI/Pr change rate (dependent variable) and watering point distance (independent variable) on each of the grazing systems.

Our experiment was lacking true replicates (Hurlbert 1984). We are conscious this makes our results conditional, particularly if vegetation dynamics showed a relative difference between paddocks before the study started. So to partially solve this situation, we performed linear regression between RDI (dependent variable) and time (yr; independent variable) for the 1988-1994 period.

\section{RESULTS}

No RDI tendency $(P>0.05)$ was detected either for the whole paddock or for each of the three zones referred to the watering point before the start of the grazing systems (Table 2). An RDI positive trend $(P<0.05)$ was detected for the whole paddock and for each of the three zones (Table 2) since the start of the grazing systems. A RDI positive trend means that NDVI of TPRR improved in relative terms with respect to NDVI of C, but does not indicate NDVI absolute positive change of each of the grazing systems. Line regression slope for the whole paddock (Table 2 ) was $0.65 \%$ per yr; hence NDVI of TPRR relatively improved 7\% in respect to NDVI of C, from 1996 to 2006. Similarly, NDVI of TPRR improved relatively in respect to NDVI of $\mathrm{C}$ in the three zones (Table 2). Nevertheless, the RDI trend was greater $(P<0.05)$ for the "near zone" $(1.13 \%$ per yr) than for the "intermediate zone" and the "far zone" $\left(0.58 \% \cdot \mathrm{yr}^{-1}\right.$ and $0.64 \% \cdot \mathrm{yr}^{-1}$, respectively, without significant differences between them).

The frequency distribution of NDVI/Pr annual change rate was different $(P<0.01)$ between grazing systems (Fig. 4$)$. We detected a significant $(P<0.10)$ NDVI/Pr positive annual change on only $6 \%$ of pixels for $\mathrm{C}$ but on $17 \%$ of pixels for TPRR. Within TPRR, significant differences $(P<0.10)$ between paddock 1 (23\% pixels) and paddock $3(10 \%)$ were detected. In those pixels with significant NDVI/Pr positive annual change, the average of NDVI/Pr annual change rate was similar for both grazing systems (0.02597 and 0.024960 NDVI units $\cdot \mathrm{mm}^{-1}$ for TPRR and $\mathrm{C}$, respectively).

Pixels with a NDVI/Pr positive annual change were located far away from the watering point, independently of the grazing system (Fig. 5). NDVI/Pr annual change rate showed a significant $(P<0.01)$ quadratic increase in relation to watering point distance in both grazing systems (Fig. 6). However, this relationship showed a higher intercept value $(P<0.01)$ and lineal term $(P<0.05)$ for TPRR than for $\mathrm{C}$, but the quadratic term was similar $(P>0.10)$ for both grazing systems. Thus, the $\mathrm{NDVI} / \mathrm{Pr}$ annual change rate was greater along all watering point distances in TPRR than in C.

\section{DISCUSSION}

Our findings showed a positive vegetation dynamics advantage of TPRR in respect to $\mathrm{C}$, which is partially consistent with the results of some studies, conducted in other regions of the world. Van Poollen and Lacey (1979), analyzing grazing system trials 
Table 2. Linear regression analysis (equation, $P$ value, and $r^{2}$ ) performed between Relative Difference Index (RDI; dependent variable) and time (yr; independent variable). The period 1988-1994 occurred before the installation of the grazing system, and 1996-2006 occurred afterward. We performed RDI regression analysis for the whole paddock and for three zones located within paddocks at three distances from the watering point (near zone $=0-1000 \mathrm{~m}$, intermediate zone $=1000-2000 \mathrm{~m}$, and far zone $=$ more than $2000 \mathrm{~m}$ ).

\begin{tabular}{|c|c|c|}
\hline Area & Before period & After period \\
\hline Total paddock & $\begin{aligned} \mathrm{RDI} & =-10.1735+3.6980 \mathrm{yr} \\
r^{2} & =0.2922, P=0.2103\end{aligned}$ & $\begin{aligned} \mathrm{RDI} & =-3.6756+0.6506 \mathrm{yr} \\
r^{2} & =0.5625, P=0.0079\end{aligned}$ \\
\hline Near zone & $\begin{aligned} \mathrm{RDI} & =0.2381+0.2954 \mathrm{yr} \\
r^{2} & =0.0162, P=0.7857\end{aligned}$ & $\begin{aligned} \mathrm{RDI} & =-5.6823+1.1286 \mathrm{yr} \\
r^{2} & =0.6131, P=0.0044\end{aligned}$ \\
\hline Intermediate zone & $\begin{aligned} \mathrm{RDI} & =-0.3274+0.4445 \mathrm{yr} \\
r^{2} & =0.0357, P=0.6847\end{aligned}$ & $\begin{aligned} \mathrm{RDI} & =-5.7115+0.5776 \mathrm{yr} \\
r^{2} & =0.2815, P=0.0931\end{aligned}$ \\
\hline Far zone & $\begin{aligned} \mathrm{RDI} & =19.7465-2.3825 \mathrm{yr} \\
r^{2} & =0.0599, P=0.5969\end{aligned}$ & $\begin{aligned} \mathrm{RDI} & =-1.3515+0.6405 \mathrm{yr} \\
r^{2} & =0.4563, P=0.0225\end{aligned}$ \\
\hline
\end{tabular}

of western US ranges, observed that a rotational grazing system increased $13 \%$ of herbage production with respect to continuous grazing systems. Holecheck et al. (2002), in a similar review, observed that forage production under a rotation grazing system averaged $7 \%$ higher than a continuous grazing system. However, these authors pointed out that, in the semiarid and desert range types, rotational grazing systems generally showed no advantage over continuous grazing on forage production and vegetation dynamics. Grazing trials performed in semiarid regions showed inconsistent results (see, e.g., Wood and Blackburn 1984; Watts et al. 1987; White et al. 1991; Guevara et al. 2002). We think that traditional fieldbased monitoring could not be appropriate to detect differences in grazing system effects on arid and semiarid vegetation, because the high temporal variability and spatial heterogeneity of this type of vegetation could mask the true impact of the

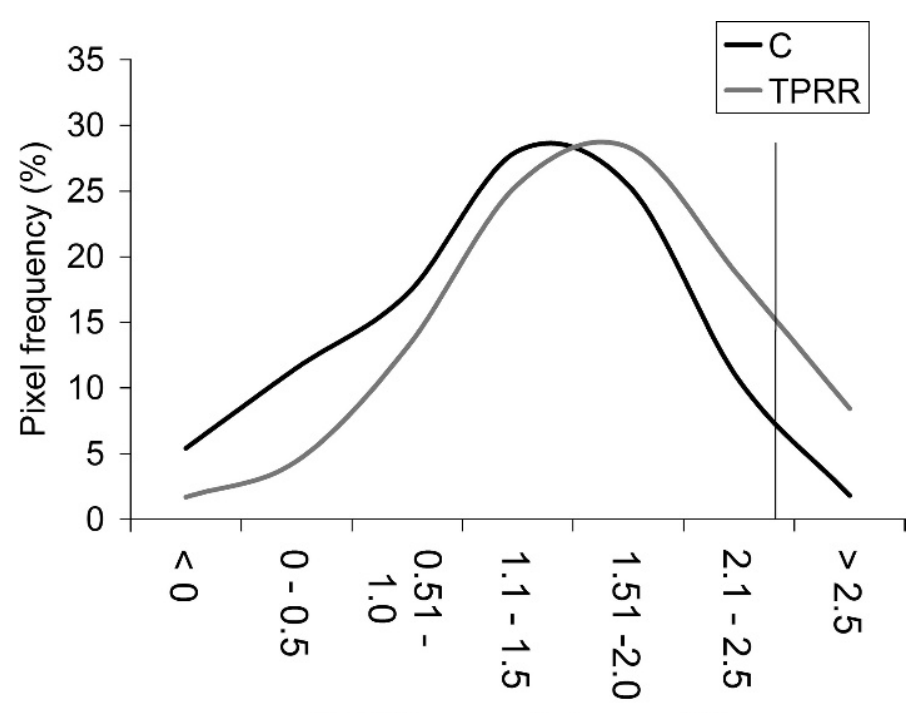

NDVI/Pr annual change (\%)

Figure 4. Frequency distribution of NDVI/Pr annual change (indicated by the straight-line slope of linear regression analysis pixel by pixel between NDVI/Pr and year from 1996 to 2006). Vertical line indicates lower limit of significant upward trend $(P<0.10)$. NDVI indicates Normalized Difference of Vegetation Index; $\mathrm{Pr}$, precipitation fallen between 1 November and the Landsat scene acquisition date; $C$, continuous grazing system; and TPRR, two-paddocks rest-rotation grazing system. grazing process. For example, grazing research has not adequately evaluated the effects of grazing at large paddocks (Bailey et al. 1996), in relation to path-specific dynamic. Indeed, Teague and Dowhower (2003) demonstrated that in large paddocks, rotational grazing allows recovery from and reduces degradation caused by patch overgrazing.

Remote sensing techniques seem to be an efficient tool for detecting differences in spatial and temporal patterns of grazing impact on vegetation. However, spectral indexes derived from Landsat TM or MSS (multi-spectral scanner) allow estimating of grazing effects on vegetation total cover (Pickup et al. 1994; Jano et al. 1998; Saltz et al. 1999; Karfs and Wallace 2001), but they are of limited value to quantify plant components (Bork et al. 1999).

Many authors used remote sensing for detecting grazing effect on plant cover in semiarid regions. For example, Pickup

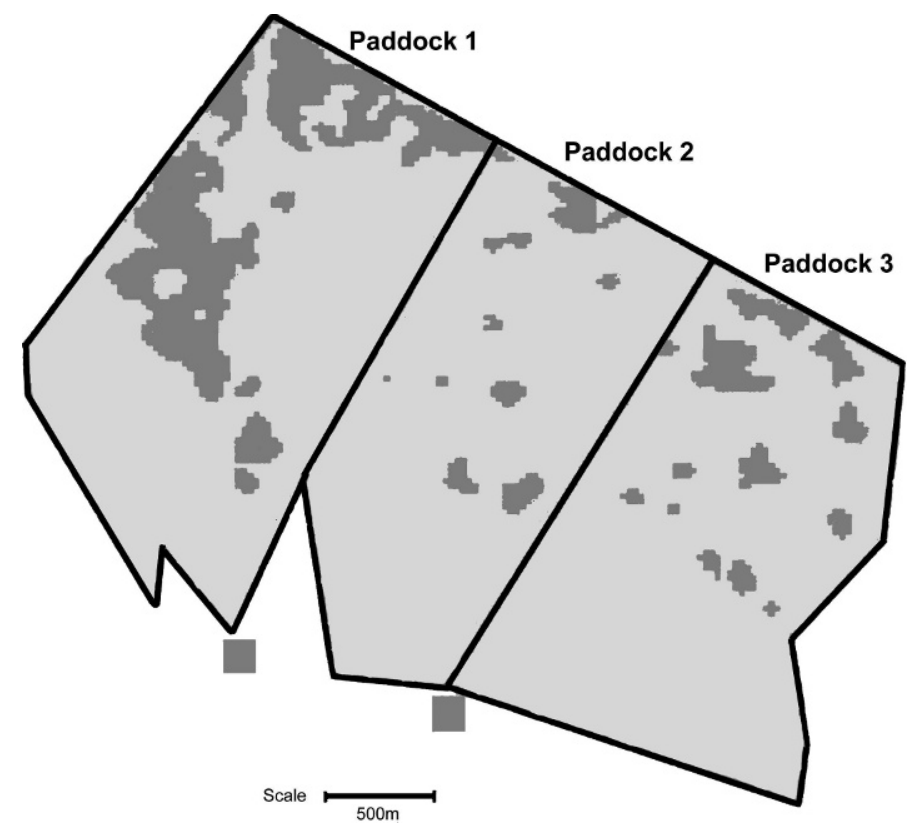

Figure 5. Spatial patterns of annual change in NDVI/Pr. Dark gray pixels show significant $(P<0.10) \mathrm{NDVI} / \mathrm{Pr}$ annual increments greater than $2 \%$. Light gray pixels showed nonsignificant $(P>0.10) \mathrm{NDVI} / \mathrm{Pr}$ annual increments less than $2 \%$. NDVI indicates Normalized Difference of Vegetation Index; Pr, precipitation fallen between 1 November to acquisition date of Landsat scene. Gray squares indicate locations of watering points. 


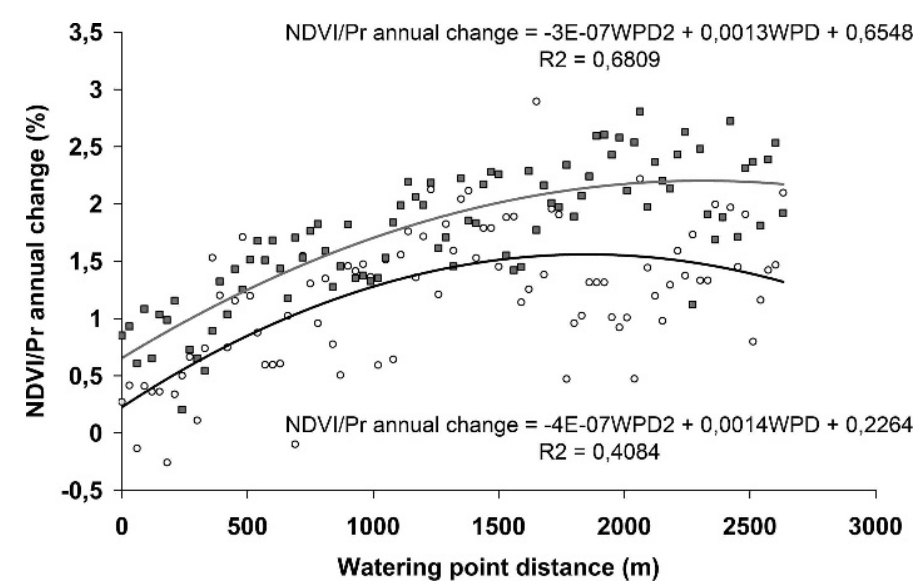

Figure 6. Relationship between spatial patterns of NDVI/Pr annual change and watering point distance (WPD). The quadratic regression model between NDVI/Pr annual change and WPD was significant $(P<0.01)$ for the Two Paddock Rest Rotation (squares) and Continuous (circles) grazing systems. NDVI indications Normalized Difference of Vegetation Index; Pr, precipitation fallen between 1 November and acquisition date of Landsat scene.

and Chewing (1994), Lind et al. (2003), and Blanco et al. (2008) observed that the grazing effect on vegetation cover varies according to watering point distance, and that these grazing gradients differed between years. However, these previous studies used remote sensing to analyze spatial patterns in grazing impact during some years but not to evaluate spatial patterns in vegetation dynamics. So we decided to focus our spatial pattern analysis of vegetation dynamics on grazing gradients. Martin and Ward (1969), in a semiarid rangeland of Arizona, observed that utilization of perennial grasses near a watering point can be reduced and herbage production increased by periodically closing the watering point in the summer (growth period). In addition, Martin and Severson (1988) reported that the "Santa Rita" grazing system can accelerate range improvement if the initial condition is poor or fair but may show little benefit if the initial condition is good. Considering that generally range conditions are related to watering point distance (near $=$ poor, intermediate $=$ fair, and far $=$ good), our results are partially in agreement with the findings of Martin and Severson (1988). Even though both grazing systems showed only significant positive NDVI/Pr annual change in far watering point pixels (Figs. 5 and 6), the greatest NDVI relative differences between grazing systems occurred in the "near zone" (Table 2).

\section{MANAGEMENT IMPLICATIONS}

Multitemporal satellite data combined with the methodological approach for processing spectral information (relative difference index and NDVI/Pr) used in the present study allows us to compare grazing system impacts on spatial and temporal vegetation patterns in a semiarid ecosystem. Our analysis would remove some limitations of traditional field sampling techniques, particularly those related to grain and extent of the spatial pattern and the spatial-time interactions of the grazing process.
We observed a slight advantage in vegetation response improvement for the TPRR over the C. According to RDI values, plant cover uptrend in TPRR was $7 \%$ higher than in $C$, considering the 11-yr study period (1996-2006). Moreover, the percentage of pixels with positive NDVI/Pr annual change was higher in TPRR $(17 \%)$ than in $\mathrm{C}(6 \%)$. Even though, in both grazing systems, positive NDVI/Pr annual change occurred only in areas farthest from watering points, TPRR showed higher relative vegetation cover (RDI) near watering points than $C$.

We consider this methodology to be an important advance for monitoring vegetation dynamics and making management decisions in grazed ecosystems of semiarid regions. However, we think that the critical advance for this methodology is to develop procedures that discriminate between forage and nonforage components of the vegetation, to base future management decisions on forage availability instead of total vegetation cover.

\section{ACKNOWLEDGMENTS}

Orlando Bazán provided valuable precipitation data. We are also grateful to José Paruelo, Rodolfo Golluscio, the associate editor, and anonymous reviewers for valuable comments.

\section{LITERATURE CITED}

Aguilera, M., D. Steinaker, M. Demaría, and A. Avila. 1998. Estados y transiciones de los pastizales de Sorghastrum pellitum del área medanosa central de San Luis, Argentina. Ecotrópicos 11:107-120. (In Spanish).

Anderson, D. L., E. Orionte, J. Vera, and P. Namur. 1977. Utilización invernal de gramíneas estivales en un establecimiento ganadero de Los Llanos de La Rioja. Instituto Nacional de Tecnología Agropecuaria. Revista de Investigaciones de Interés Agropecuario 35:321-329. (In Spanish).

Bailey, D. W., J. Gross, E. Laca, L. Rittenhouse, M. Coughenour, D. Swift, and P. Sims. 1996. Mechanisms that result in large herbivore grazing patterns. Journal of Range Management 49:386-400.

Baret, F., and G. Guyot. 1991. Potentials and limits of vegetation indices for LAl and APAR assessment. Remote Sensing of Environments 35:161-173.

Bastin, G. N., G. Pickup, V. Chewings, and G. Pearce. 1993. Land degradation assessment in Central Australia using a grazing gradient method. Australian Rangeland Journal 15:190-216.

Baź́n, 0. 1993. Información climática de 13 años del Campo Experimental "Las Vizcacheras." La Rioja, Argentina: Instituto Nacional de Tecnología Agropecuaria, Estación Experimental Agropecuaria La Rioja, Publicación interna. 15 p. (In Spanish).

Blanco, L. J., M. Aguilera, J. Paruelo, and F. Biurrun. 2008. Grazing effect on NDVI across an aridity gradient in Argentina. Journal of Arid Environments 72:764-776

Bork, E. W., N. West, K. Price, AND J. Walker. 1999. Rangeland cover component quantification using broad (TM) and narrow-band (1.4 NM) spectrometry. Journal of Range Management 52:249-257.

Briske, D. D., J. Derner, J. Brown, S. Fuhlendorf, W. Teague, K. Havstad, R. Gillen, A. AsH, AND W. WilLms. 2008. Rotational grazing on rangelands: reconciliation of perception and experimental evidence. Rangeland Ecology and Management 61:3-17.

Bryant, N. A., L. Johnson, J. Brazel, R. Balling, C. Hutchinson, and L. Beck. 1990. Measuring the effect of overgrazing in the Sonoran desert. Climatic Change 17:243-264.

Chavez, P. S. 1989. Radiometric calibration of Landsat Thematic Mapper multispectral images. Photogrammetric Engineering and Remote Sensing 55:1285-1294. 
Crawley, M. J. 1996. The structure of plant communities. In: M. J. Crawley [ed.]. Plant ecology. London, UK: Blackwell Science. p. 475-531.

Gower, S. T., C. KuChariK, AND J. Norman. 1999. Direct and indirect estimation of leaf area index, fAPAR and net primary production of terrestrial ecosystems. Remote Sensing of Environments 70:29-51.

Guevara, J. C., O. Estevez, C. Stasi, and J. Gonnet. 2002. Perennial grass response to 10-year cattle grazing in the Mendoza plain, mid-west Argentina. Journal of Arid Environments 52:339-348.

Holechek, J. L., H. Gomez, F. Molinar, and D. Galt. 2002. Grazing studies: what we've learned. Rangelands 21:12-16.

Holm, A. M., S. Cridland, and M. Roderick. 2003. The use of time-integrated NOAA NDVI data and rainfall to asses landscape degradation in the arid shrubland of Western Australia. Remote Sensing of Environment 85:145158.

Hurlbert, S. H. 1984. Pseudoreplication and the design of ecological field experiments. Ecological Monographs 54:187-211.

Jano, A. P., R. Jefferies, and R. Rockwell. 1998. The detection of vegetational change by multitemporal analysis of LANDSAT data: the effects of goose foraging. Journal of Ecology 86:93-99.

JENSEN, J. R. 1996. Introductory digital image processing: a remote sensing perspective. Englewood Cliffs, NJ, USA: Prentice-Hall.

Karfs, R. A., and J. Wallace. 2001. An analysis of temporal change at rangeland monitoring site using remote sensing in northwest Australia. IEEE Transactions on Geoscience and Remote Sensing 39:988-990.

LAnge, R. T. 1969. The piosphere: sheep track and dung patterns. Journal of Range Management 22:396-400.

Levin, S. A. 1978. Pattern formation in ecological communities. In: J. S. Steele [ED.]. Spatial pattern in plankton communities. New York, NY, USA: Plenum Press. p. 433-465.

Lind, M., K. Rasmussen, H. Adriansen, and A. Ka. 2003. Estimating vegetative productivity gradients around watering points in the rangelands of Northern Senegal based on NOAA AVHRR data. Geografisk Tidsskrift, Danish Journal of Geography 103(1):1-15.

Martin, S. C., And K. Severson. 1988. Vegetation response to the Santa Rita grazing system. Journal of Range Management 41:291-295.

Martin, S. C., And D. Ward. 1969. Rotating access to water to improve semidesert cattle range near water. Journal of Range Management 22:22-26.

Morello, J. H., C. Protomastro, L. Sancholuz, and C. Blanco. 1985. Estudio macroecológico de Los Llanos de La Rioja. Serie del Cincuentenario de la Administración de Parques Nacionales 5:1-53.

Noy MeIR, I. 1973. Desert ecosystem: environment and producers. Annual Review of Ecology and Systematics 4:25-41.

Paruelo, J. M., M. Garbulsky, J. Guerschman, and E. Jobbagy. 2004. Two decades of normalized difference vegetation index changes in South America: identifying the imprint of global change. International Journal of Remote Sensing 25:2793-2806.

Paruelo, J. M., And R. Golluscio. 1994. Range assessment using remote sensing in Northwest Patagonia (Argentina). Journal of Range Management 47: 498-502.
Pickup, G., G. Bastin, and V. Chewings. 1994. Remote sensing-based condition assessment for nonequilibrium rangelands under large scale commercial grazing. Ecological Applications 4:497-519.

PICKUP, G., AND V. CheWIngs. 1994. A grazing gradient approach to land degradation assessment in arid areas from remotely sensed data. International Journal of Remote Sensing 15:597-617.

Prince, S. D., E. Brown de Colstoun, and L. Kravitz. 1998. Evidence from rain use efficiencies does not indicate extensive Sahelian desertification. Global Change Biology 4:359-374.

Romero, A. 1995. Mapa de suelos de los campos "Las Vizcacheras" y "Los Cerrillos." Informe final. La Rioja, Argentina: Instituto Nacional de Tecnología Agropecuaria, Estación Experimental La Rioja. 45 p. (In Spanish).

Saltz, D., H. Schmidt, M. Rowen, A. Karniel, D. Ward, and I. Schmidt. 1999. Assessing grazing impacts by remote sensing in hyper-arid environments. Journal of Range Management 52:500-507.

Sellers, P. J., J. Berry, G. Collatz, C. Field, and F. Hall. 1992. Canopy reflectance, photosynthesis and transpiration. III. A reanalysis using improved leaf models and a new canopy integration scheme. Remote Sensing of Environment 12:187-216.

Song, C., C. Woodcock, K. Seto, M. Lenney, and S. Macomber. 2001. Classification and change detection using Landsat TM data: when and how to correct atmospheric effects? Remote Sensing of Environment 75:230-244.

Teague, W. R., And S. Dowhower. 2003. Patch dynamics under rotational and continuous grazing management in large, heterogeneous paddocks. Journal of Arid Environments 53:211-229.

Telllet, P. M., J. Barker, B. Markham, R. Irish, G. Fedosejevs, and J. Storey. 2001. Radiometric cross-calibration of the Landsat-7 ETM+ and Landsat-5 TM sensors based on tandem data sets. Remote Sensing of Environment 78:39-54.

Teillet, P. M., And G. Fedosejevs. 1995. On the dark target approach to atmospheric correction of remotely sensed data. Canadian Journal of Remote Sensing 21:373-387.

TUCKER, C. J. 1979. Red and photographic infrared linear combinations for monitoring vegetation. Remote Sensing of Environment 8:127-150.

Urban, D. L., R. O'Neill, and H. Shugart, JR. 1987. Landscape ecology: a hierarchical perspective can help scientists understand spatial patterns. BioScience 37:119-127.

Van Poollen, H. W., and J. Lacey. 1979. Herbage response to grazing systems and stocking intensities. Journal of Range Management 32:250-253.

Washington-Allen, R. A., N. West, R. Ramsey, and R. Efroymson. 2006. A protocol for retrospective remote sensing-based ecological monitoring of rangelands. Rangeland Ecology and Management 59:19-29.

Watts, C. R., L. Eichnorn, and R. Mackie. 1987. Vegetation trends within restrotation and season-long grazing systems in the Missouri River Breaks, Montana. Journal of Range Management 40:393-396.

White, M. R., R. Piper, G. Donart, and L. White Trifaro. 1991. Vegetational response to short-duration and continuous grazing in south-central New Mexico. Journal of Range Management 44:399-403.

Wood, K. M., And W. BLACKBuRn. 1984. Vegetation and soil responses to cattle grazing systems in the Texas rolling plains. Journal of Range Management 37:303-308. 